\title{
Improving local land governance? Exploring the linkages between land governance reforms, institutional pluralism and tenure security in Burundi
}

\section{Rosine Tchatchoua-Djomo}

To cite this article: Rosine Tchatchoua-Djomo (2018): Improving local land governance? Exploring the linkages between land governance reforms, institutional pluralism and tenure security in Burundi, The Journal of Legal Pluralism and Unofficial Law, DOI: 10.1080/07329113.2017.1419403

To link to this article: https://doi.org/10.1080/07329113.2017.1419403

曲 Published online: 02 Jan 2018.

Submit your article to this journal ¿

Џ Article views: 11

Q View related articles $\sqsubset$

View Crossmark data ¿ 


\title{
Improving local land governance? Exploring the linkages between land governance reforms, institutional pluralism and tenure security in Burundi
}

\author{
Rosine Tchatchoua-Djomo (iD) ${ }^{a, b}$ \\ aAfrican Studies Centre Leiden (ASCL), Leiden University, Leiden, The Netherlands, PO Box 9555, 2300RB; \\ ${ }^{b}$ Department of Social Sciences, Wageningen University, Wageningen, PO Box 8130, 6700EW, \\ The Netherlands
}

\begin{abstract}
Reforms in land governance are assumed to significantly enhance the security of tenure in conflict-affected countries, through stimulating the resolution of land disputes, contributing to better control of property rights and reorganising the institutional framework for land management. Yet, this paper highlights the ambiguous outcomes of such reforms in situation of institutional multiplicity. Fieldwork in Ngozi province in northern Burundi points out how land-related reforms such as decentralising the administrative authority at the communal and hill levels and policy reforms in the formalisation of property rights have positive impacts in terms of dealing with specific land disputes and fostering local feelings of tenure security in the aftermath of the 2000 Arusha Peace Agreement. However, land governance reforms have also fuelled the proliferation of land governing institutions and fostered confusion among state and non-state authorities about which rules to apply and their roles in mitigating tensions over landownership and enforcing property rights. Actually, while introducing new laws, policies, institutions and practices, land governance reforms have produced mixed effects in securing local tenure for most community members and increased contestations against the authority of government representatives at the local level.
\end{abstract}

\section{ARTICLE HISTORY}

Received 1 August 2017

Accepted 17 December 2017

\section{KEYWORDS}

Burundi; governance

reforms; institutional multiplicity; land disputes; tenure security

\section{Introduction}

Violent conflicts significantly affect land tenure and land governance. In post-war settings, forced displacement is likely to result in increasing competition for natural resources through the proliferation of overlapping claims over access to land and property rights (Fischer and Vollmer 2009; Crisp 2010). Beyond their fundamental contribution to identity and belonging, livelihood strategies, and agrarian economies in most developing countries (Kamungi, Oketch, and Huggins 2005; Lund 2011), access to land and property rights are instrumental for consolidating peace, and for constituting and negotiating authority and power in the aftermath of violent conflicts (Lund and Boone 2013; Sikor 
and Lund 2009; Unruh 2003; Unruh and Williams 2013). In this respect, a common response of policy makers to these challenges has often been enhancing dispute resolution and guaranteeing the security of tenure and property rights through the adoption of policies concerning housing, land and property restitution for refugees and displaced people, and decentralising land services. Such reforms are foregrounded in peace agreements, which presumably provide a collectively binding formal framework for addressing land-related grievances, redressing rural livelihoods, (re-) establishing effective land administration and institutions, and contribute to post-war recovery and reconstruction (McCallin 2013; Todorovski 2016; Unruh and Williams 2013).

Yet, the question remains how such land reforms grounded in peace agreements work out in practice and whether they effectively contribute to strengthening local land governance and enhancing tenure security in conflict-affected settings. Actually, land governance reforms may often fail to reach the expected outcomes of regulating and enforcing land management and mitigating land disputes, or increasing localised and participatory decision-making processes (McCallin 2012; Unruh 2005). They may fuel the proliferation of new rules and institutions, and induce competition among land-governing actors, and even (re-) activate questions of identity and ethnic belonging (Justin and van Leeuwen 2016; Kobusingye, van Leeuwen, and van Dijk 2016).

This paper therefore analyses to what extent land governance reforms contribute to institutional multiplicity in land governance and effectively impact local tenure (in-) security, with regard to dispute resolution and the formalization of property rights for different social actors in the aftermath of the 2000 Arusha Peace Agreement in Burundi. ${ }^{1}$ It also intends to examine the competition about the exercise of authority among several land-governing actors and which rules to apply. Although contemporary scholars and experts have provided relevant insights into the governance of land disputes in Burundi (International Crisis Group 2014b; Ndayirukiye and Takeuchi 2014; Nyenyezi Bisoka and Ansoms 2012; van Leeuwen 2010) and the recent land reforms and localised land registration (Betge, Irutingabo, and Westerbeek 2017; International Crisis Group 2014a; Munezero and Niyonkuru 2016), they often overlook the actual outcomes of such land governance reforms in terms of multiplying policies, rules, laws and institutions, and in complicating governance processes and practices. The analysis develops on the basis of work of scholars such as Lund and Boone (2013), Peluso and Lund (2011) and Sikor and Lund (2009), who point out the interconnectedness between notions of authority and control and the social, institutional and political processes and practices related to the governance of land and property rights. Actually, these scholars demonstrate the critical and strategic role of land governance for negotiating property and power relations, and institutional and political control.

This paper argues that the land reforms grounded in the 2000 Arusha Peace Agreement add more complexity to preexisting situation of institutional multiplicity in land governance and fuel confusion and institutional competition about the rules applied and authority structures. Land tenure reforms create opportunities for (non-) state institutional actors for redefining, reinforcing or negotiating decision-making power, authority and control. Furthermore, they lead to critical ambiguities in land administration and land service provision, contested notions of tenure (in-) security, and to contested relations of legitimacy and authority between various institutions. 
This paper is based on qualitative fieldwork in Ngozi province in northern Burundi, between June 2013 and November 2014. The fieldwork combined interviews, focus group discussions, participation in workshops and seminars, and observation. A total of 55 semi-structured interviews was therefore realised with land users (men/women, displaced/non-displaced), family heads, traditional elders (mushingantahe, singular; bashingantahe, plural; Kirundi), government representatives at various levels (hill ${ }^{2}$, commune, province, central), and representatives of international development agencies and civil society organisations involved in designing and implementing land governance reforms. The informants were selected in order to represent the diversity of social and institutional categories related to land governance. This was carried out based on their position in authority structures, geographical accessibility, willingness to participate in the research, and involvement in specific land disputes and land registration operations. The interviews explored actual configuration of actors, processes and practices of land governance, and how land disputes resolution and the formalisation of property rights are regulated and managed. Additionally, eight focus group discussions gathering a total of 52 people were organised with hill authorities, bashingantahe, and local community members (men and women separately). Different topics including customary rules, land allocation and ownership, land dispute resolution, land registration, land and power relations were covered during these meetings. The researcher also participated in several stakeholders' meetings organised by the Coordination Unit of the national land programme, and in workshops, seminars, and national and regional conferences. These meetings gathered donors, representatives of international development agencies, representatives of local and central government structures, and representatives of civil society organizations around issues related to on-going processes of land law and policy reforms and their implementation. Through these gatherings, the researcher also assessed the interactions and power relations among formal/informal local/central institutions, and the challenges encountered in land reform processes and the implementation of new policies and regulations.

The next section presents the approach for analysing the impacts of land reforms and institutional pluralism in governance processes and practices. The third section examines the historical development and sheds light on the institutional dynamics in land governance in Burundi, with a particular focus on the aftermath of the 2000 Arusha Peace Agreement. Through the case study of Ngozi province, the fourth section shows the manifold outcomes of land governance reforms in terms of diversifying the number, roles and rules of land-related institutions at the local level, enhancing the resolution and prevention of particular land disputes, and increasing the authority of the state in land registration. Moreover, it explores how land governance reforms contributed to mixed perceptions of the state and contrasting notions of secure land tenure at the local level. The last section discusses challenging dynamics in local land governance in conflictaffected Burundi and elaborates some conclusions.

\section{Analysing land governance reforms and institutional pluralism}

In this paper, the outcomes of reforms on the governance of land disputes and the security of tenure in the aftermath of peace agreements are analysed through the concepts of legal pluralism and institutional multiplicity. The notion of legal pluralism is considered at the intersection of legal, political and social science; it refers to the coexistence of multiple 
normative or institutional orders and their overlap within a given social setting (Griffiths 1986; Unruh 2003). By normative or institutional orders, Catherine Boone refers to structural frameworks of norms, rules or conventions aiming to sanction collectively binding decisions; these also entail loci of political authority over property rights and the connections within and across different levels of land governance (Boone 2013, 190). These may involve state law, customary law, religious law, project (donor) regulations, organizational law, and other local or hybrid norms (Meinzen-Dick and Pradhan 2002). In practice, institutional orders are dynamic and adjustable to social change. They can be interdependent and intersecting, as some institutional actors may borrow and apply norms, rules and conventions from other institutional repertoires while fulfilling given land-governing roles. Consequently, land governance processes underscore ideas of broader, often complex processes, and dynamic interactions within and between diverse formal and informal land governing actors with different relations of legitimacy and authority and notions of which rules to apply. The ensuing competition with respect to whom is authorized to take charge and under what specific circumstances, and which regulatory framework or norms to apply for particular land and property issue greatly determines the outcomes of governance reforms (Kobusingye, van Leeuwen, and van Dijk 2016).

Actually, this paper demonstrates that examining land governance reforms merely as processes of (re-) establishing the authority and legitimacy of the central government and its decentralised structures in dealing with local land and property issues, and of creating opportunities for clarifying, negotiating and formalising property rights over (pre-war) landholdings, is insufficient for a critical appraisal of why they fail to produce the intended impacts in conflict-affected settings. In analysing the intersection among land tenure, legal pluralism and peace-building, Unruh (2003) points out that efforts aimed to address secure access to rural land and property claims during and following violent conflicts are likely to foster the precarious rise of multiple and overlapping systems of norms, rules and conventions, and thus add more confusion in already existing settings of tenure insecurity. As a matter of fact, such transformations in land governance have significant impacts in the rearrangement of power relations among a diversity of actors at different levels, in unfolding profuse avenues for dealing with land access and property claims, and even in intensifying struggles over land tenure (Kobusingye, van Leeuwen, and van Dijk 2016; van Leeuwen 2017).

In practice, land governance reforms occur in preexisting already complex settings of legal pluralism in which multiple institutions sometimes with diverging interests, asymmetrical power relationships and overlapping sources of legitimacy and authority interact with one another, influence and enforce land and property issues. In conflictaffected contexts, land tenure systems are generally battlefields for multiple state and non-state actors for negotiating authority and legitimacy relations that are crucial in determining access, use and control over land (Hirblinger 2015). Often, emerging decision-making structures at various governance levels may reflect contested reconfigurations of power relations and polarised politics, and therefore display an amplification of previous situations of legal pluralism. Empirical observations suggest that under such conditions policy changes are susceptible to enhance contestations over which rules to enforce, especially when international frameworks for post-war resource allocation are strongly imposed on existing domestic land tenure systems (Joireman and Meitzner Yoder 2016; Unruh 2005). For instance, it is a challenging task for state 
actors to translate international legal standards on post-conflict property restitution from paper agreements into local settings where the reach or the authority of the state is contested or limited (Joireman and Meitzner Yoder 2016). In a situation of legal pluralism, access to resources is always negotiable and uncertain, being the result of social and power relations (Berry 2009; Meinzen-Dick and Pradhan 2002). Resource users usually appeal to multiple institutional orders while negotiating access to resources in contexts of competing claims and changing environmental and social conditions - a phenomenon described as forum shopping (von Benda-Beckmann 1981). Nevertheless, rules, rights and practices are susceptible to be challenged and cancelled through resort to state law or state actors (Lavigne Delville 1999).

Although forum shopping allows parties with competing claims strategic scope of action to target specific institutions to present their claims, it may also put them under multiple institutional pressures. The most powerful institutions may impose their procedures and rules, and therefore restrict access to and the authority of those institutions legitimised and privileged by contesting parties. For instance, in his account on how different donors, international development organisations, and the central government-led attempts to improve local land tenure security have resulted in contrasted impacts on local tenure insecurity and peace-building during the post-conflict and post-disaster period in Aceh in Indonesia, Arthur Green highlights that failure to understand the interconnectedness among the existing diversified norms, customs and conventions, and their roles in shaping local land access and ownership during the conflict has misguided the land reform process (Green 2013). Hilaire Tegnan makes similar analysis in his study of land administration and legal pluralism in West Sumatra by demonstrating that, instead of preventing and settling local land disputes, legal reforms and decentralisation of land management rather result in increasing struggles over land due to uncoordinated and contradictory regulations embedded in customary, religious, and statutory institutional orders, to overlooking the complexity of customary law and tenure systems, and to unfulfilled political promises (Tegnan 2015).

From what precedes, analysing the current outcomes of land governance reforms implies a closer look at the transformations in the regulations, norms and conventions determining access to land and property rights, the reconfigurations of roles, power relationships and everyday governance processes and practices of a variety of (non) state actors, and how different resource users navigate the diversification of institutions while making their claims to land. As the case study of conflict-affected Burundi will demonstrate, land governance reforms have relatively improved the resolution and prevention of certain land disputes and the land administration system. However, they have failed in bringing a solution to the competing claims over the land occupied by the internally displaced people (IDPs) and in improving local security of tenure. Land reforms play into the proliferation of institutions and unequal relations of authority and legitimacy among various institutional actors in regulating local land tenure and property rights. This has further consequences on how the roles of the state and different institutional actors are understood, on the nature of the relations between land governing authorities, as well as on how secure land tenure is perceived. Prior to exploring empirical evidence of such dynamics of land reforms, the institutional entanglements in land governance, and their repercussions for tenure security, the next section explores the historical background of land governance in Burundi. 


\section{Historical development of land governance in Burundi}

An overview of the changes in land tenure in Burundi is required to understand its current forms and to assess the nature and extent of recent reforms. Based on Gilbert Bigirimana (2013b), these proceedings can be explored along three historical periods: (i) the pre-independence period characterised by a monarchy ruling system followed by a colonial regime, (ii) the tumultuous post-independence period until the signing of the 2000 Arusha Peace Agreement, and (iii) the aftermath of the 2000 Arusha Peace Agreement characterised by several land governance reforms aimed at enhancing tenure security through land disputes resolution and the registration of property rights.

\section{The pre-independence period}

Before the colonisation by the Germans, local populations entrusted the Burundian King - the Mwami - as their main spiritual and political leader, to govern land and other natural resources, through a customary and decentralised authority system involving the princes, royal elites, customary elders or bashingantahe, and area chiefs. Land was collectively held and used within patrilineal clans and lineages. To acquire a piece of land or to expand landholdings, family heads were introducing their requests to the area chiefs. Customary elders played the role of custodians of the local memory on land tenure, and of legal authorities in case of disputes.

The introduction and enforcement of the German (1903-1916) and the Belgian (19191962) colonial rules significantly affected the Burundian customary land tenure. The power of customary authorities in land allocation, use and control were tremendously altered through the introduction of formal written legislation and mechanisms for enhancing the demarcation and registration of property rights on land. In fact, under the Belgian colonial ruling, statutory land tenure was developed and enforced along racial differentiation between the Belgian and other white foreigners, and local/indigenous people. Accordingly, land was divided in three major property regimes: customary property, state land, and private/individual (registered) property.

Following the 1959 Rwandan Revolution and the influx of Rwandan Tutsi refugees in Burundi, land control became a key concern in Burundi, as the Mwami and the royal elites engaged in social and political movements to get their independence from the colonial rulers. In this respect, in July 1960, in a blundering effort to counteract the rise of popular claims for independence and to reinforce its authority, the colonial administration issued an official statement enforcing the transfer of all non-registered customarily owned land into the state property regime, with the direct consequence of denying customary entitlements. Nevertheless, toward the independence of Burundi, the Mwami issued a Royal Edict in August 1961 allowing for the formal recognition and registration of property rights on customary land ${ }^{3}$ in order to reinforce his legitimacy and authority (de Clerck 1970, 1971). Such enforcement of the formalisation of individual property rights on customary land was later solidified within the 1962 Burundian Constitution (Art. 11 and 12).

\section{The tumultuous post-independence period: 1962-early 2000 s}

The post-independence period was marked by divisions within the Burundian political elites, which led to the suppression of the constitutional monarchy in favour of 
authoritarian and militarised regimes dominated by Tutsi elites (1966-2005) and Hutu elites (2005-present $)^{4}$. After the collapse of the constitutional monarchy and royal elites after a successful military coup d'état in November 1966, led by Captain Michel Micombero (Ndarishikanye 1999), the existing land tenure systems, rules and norms remained in use with few changes. Confronted with a new political and dominating leadership and elites with ramifications within local communities, the formal land legislation was met with very little enthusiasm by local populations for three main reasons. First, the 1961 Royal Edict and the 1962 Constitution provided very little details about the implementation of official land laws. For instance, de Clerck (1971) reported that officials from the Ministry of Agriculture were facing difficulties in defining operational frameworks for implementing the registration and transfer of property rights, and simultaneously for reconciling formal land registration with the customary patrilineal land tenure. Second, despite a significant bend in the authority and legitimacy of customary institutions and norms due to political struggles for power and control, most peasants did not trust formal institutions and government representatives to manage customary owned land; furthermore, many rural land owners were reluctant to spend limited financial resources for the registration of customary legitimated entitlements and for acquiring land titles (Bukera 1970b). Third, in 1970, the regulation on the implementation of land registration had been revised by the contested political establishment, raising the rate of cadastral and titling fees, and therefore limiting the access of many citizens to land rights registration in favour of the political elites (Bukera 1970a; de Clerck 1971). It is in such context that local uprising and ethno-political killings occurred in April 1972, with the most severe outbreak in southern provinces of Burundi. This led to the exile of hundreds of thousands Hutu civilians to neighbouring countries and the abandonment of their land and properties. This was mainly to the advantage of most political elites and militants of the dominant political party Union pour le progrès national (UPRONA). ${ }^{5}$

Few months after the accession of Jean-Baptiste Bagaza as the head of state in November 1976, he introduced four major legal reforms to regulate land rights and their formalisation. Bagaza's official discourse was framed around the restoration of national unity through modernising government institutions, with a particular focus on land governance. His first legal reform was the promulgation of a decree law in 1976 binding the incorporation of customary owned land within the state land properties. ${ }^{6}$ The side effects of the provisions of this law were the extensive regularisation of the grabbing of Hutu refugees' land and other informally allocated land across the country. The second legal change was the abolition of the customary patronage institution Ubugererwa ${ }^{7}$, which contributed to endowing many abagererwa (servants) with property rights on shebuja's (landlords) land they have exploited for more than seven years. The third legal change was the extension of the prescription rule to customary owned land ${ }^{8}$. In other words, every land occupied over a period of 30 years regardless of the nature of the acquisition modes ought to be automatically converted into state-acknowledged full ownership. The fourth legal change consisted in the compilation and promulgation of the first Burundian Land Code in 1986. It formed an essential legal instrument embodying principles and rules applicable to the articulation and formalisation of land ownership rights. A great emphasis of the 1986 Land Code was the empowerment of provincial government authorities in allocating land and the setting of a decentralised land administration and titling system. However, due to political turmoil and financial and technical limitations, the expected 
decentralisation of land services provision did not follow. For instance, instead of setting up decentralised land titling structures, the existing Division of Land Titles remained the central government structure empowered to deliver land titles, and was simply moved from the Ministry of Agriculture to the Ministry of Justice. This institutional transfer aimed to stress and reinforce the authority of the judiciary administration in delivering and sanctioning land titles and property rights. Likely, the 1986 Land Code did not bring meaningful changes in the governance practices, and therefore received many criticisms from land experts who argued it was a mere replication of colonial land laws and failed to reflect and address the duality of land tenure regimes represented by the customary and statutory land systems (Bigirimana 2013b; Kohlhagen 2011a).

Between the late 1980s and the late 1990s, several attempts to change the legal and institutional frameworks and policies have failed or have been interrupted because of further military takeovers, localised land-related violence and new waves of forced displacement. Soon after the seizure of power by Pierre Buyoya in 1987, he established the Ministry of Regional Planning and Tourism in 1988, which was empowered to set up a specific administration for managing the environment and land services. Nevertheless, considering the centralisation of decision-making power, the limited technical and financial capacity of the government, and the prevalent political instability, this new government structure had limited reach to local communities where the bulk of land-related operations and problems were located.

A further reform initiative was the drafting of a regulatory framework for the improvement of the governance of customary land. A key idea supporting this reform process was the rising concerns of some international actors about the failure of land titling to ensure tenure security in most African countries, and the need to acknowledge and to integrate the socio-economic realities of rural farmers into land policies. Subsequently, thanks to the technical and financial support of the United Nations Organisation for Food and Agriculture, a project to reform the Burundian land laws was launched in early 1990s with the aim of designing a Rural Land Code focusing on the reinforcement of local land tenure security, agricultural development and natural resource management. More importantly, the intended legal framework and policies were meant by (inter) national actors as a mitigation mechanism to the rising contestations over land access and property rights by increasing the protection of customary land rights and arrangements through an independent investigation process on litigious land and a generalised land registration system (Kohlhagen 2011a). Unfortunately, the eruption of a protracted civil war in 1993 interrupted this land reform initiative. In fact, under the existing 1986 land code, the country experienced a considerable rise of land disputes and several illegal land allocations, especially on rural land. By fostering the recognition of customary rules and the formalisation of customary land entitlements the intended legislation reform was expected to diffuse those tensions over land in local communities.

\section{The 2000 Arusha Peace Agreement and its aftermath}

By the end of the civil war, the signing of the Arusha Peace Agreement in 2000 stimulated the Burundian policy makers to pick up the thread of land governance reforms as a key requirement for peace-building and state reconstruction, considering the various challenges related to refugees' repatriation, competing claims over land access and property 
rights, and local land governance in the post-war setting. These land reforms were also intended to transform the centralised and undemocratic governance practices under the former political regimes. Since 2000 therefore, two key areas of land governance in Burundi have changed tremendously: the resolution of land disputes, and the registration of property rights and land administration.

The 2000 Arusha Peace Agreement acknowledged the importance of setting up a specialised government structure dealing with displacement-related land disputes. Therefore, the Commission nationale pour la réhabilitation des sinistrés (CNRS) was first created in 2003, but was later replaced by the Commission nationale des terres et autres biens (CNTB) in 2006 after the accession of Pierre Nkurunziza as the head of state. Since then the CNTB is officially the prime institution allowed to sort out local land disputes involving former refugees and IDPs. Furthermore, the Cour spéciale des terres et autres biens (CSTB) was formed in 2014 as the supreme judiciary structure empowered to pronounce judgements on appeals to the final decisions rendered by the CNTB on displacementrelated land disputes. For other general local land disputes such as encroachment of land boundaries, contested land sales, or intra-family disputes about sharing inherited land, local people used to refer to other existing institutions such as family heads, traditional elders, local government authorities or judicial authorities.

Moreover, the 2000 Arusha Peace Agreement provided for the reorganisation of the existing land administration system and the revision of the 1986 Land Code $^{9}$ to address land tenure insecurity and to improve land services provision in general. For instance, through a presidential decree in 2003, the existing Division of Land Titles was renamed into the Directorate of Land Titles and National Cadastre in order to stress the relevance of the operations of demarcating, measuring and registering land.

Parallel to this, a draft revised Land Code proposal was produced in 2004. Yet, this proposal was criticised for its strong congruency with the initial land law document. For instance, Dominik Kohlhagen noted that, despite its 650 remarkable articles content, its structure was very similar to the 1986 Land Code, and some legal ambiguities, such as the thirty years prescription rule and the absence of dispute resolution mechanisms, remained unaltered (Kohlhagen 2011a). Amidst the first post-war presidential elections in Burundi, the draft revised Land Code was put on hold. Yet, land governance remained at the centre of the electoral campaigns and political debatesby the framing of displacement-related land disputes along ethnic and political antagonism (APDH and Global Rights 2005).

With the accession of Pierre Nkurunziza ${ }^{10}$ as the head of state in 2005 , the idea of decentralising government structures and revising land laws was explored further. Effectively, with respect to the 2005 Constitution, the Burundian government adopted a decentralisation law ${ }^{11}$ aimed at creating, reorganising and empowering communal and hill administrative authorities, in order to increase the presence of the state at the local level. Moreover, as the new political leadership did not participate in the decision-making process that led to the 2004 draft revised Land Code, it rejected this legal reform proposal (Bigirimana 2013b; International Crisis Group 2014a; Kohlhagen 2011a). Instead, in 2007, the Nkurunziza government engaged in another land-related legal and institutional reform process with the technical and financial support of international aid agencies. A core idea guiding this reform process was the restoration and the modernisation of the land administration and tenure systems, with the assumption that this would contribute to strengthening land governance, reducing land disputes and fostering the security of 
tenure. A revised Land Code was therefore adopted in 2011, with a focus on the creation of the communal land registration office (service foncier communal, SFC). This is a localised land registration structure within the decentralised communal administration, with the dual goal of enhancing the formalisation of customary land rights at lower costs and reducing local land disputes. It is intended to deliver land certificates, supervise and monitor land transfers on customary land, and to assist other land institutional authorities in dispute resolution and mapping state-owned land.

In parallel, the Directorate of Land Titles and National Cadastre was split into two distinct central structures in 2007: the Directorate of Land Titles remained within the Ministry of Justice while the Directorate of National Cadastre was moved to the Ministry of Public Works; the latter was redirected to the Ministry of Water, Environment, Regional Planning and Urban Development (MEEATU, French acronym) in 2011. Nevertheless, the decentralisation of these two administration systems to facilitate the formalisation of property rights is not effective across the whole territory, and is limited to few provinces. There exist only three government offices in charge of land titles, respectively in Bujumbura, Gitega and Ngozicities. There are four regional cadastre offices that cover a number of provinces: Bujumbura office (Bujumbura City, rural Bujumbura, Bubanza, Cibitoke), Bururi office (Bururi, Rumonge, Makamba, Rutana, Mwaro), Gitega office (Gitega, Karusi, Ruyigi, Cankuzo), and Ngozi office (Ngozi, Kayanza, Muyinga, Kirundo). In order to facilitate access to their services, the regional land titling and cadastre structures work in collaboration with the MEEATU provincial offices in charge of regional development and urban planning. These provincial structures provide information about the different steps of the titling procedure, deliver the official letter authorising payments for acquiring land on state-owned land, and the certificate of conformity on customary land to people willing to formalise individual property rights. By the end of the 2000s, it was recorded a total of only 46,000 land plots registered in the National Land Titles Register, which is less than one per cent of the country size (Kohlhagen 2011a, 5).

Even though the Burundian government is dedicated to uplifting its land administration and local land governance, government officials at provincial, communal and hill levels, non-governmental organisations (NGOs) and civil-society representatives interviewed generally argued that the actual distribution and implementation of regulations display critical ambiguities. The implications of such ambiguities at the local level are crucial for our analysis. While policy, legal and institutional changes aim at improving and strengthening land governance in terms of efficient land administration, tenure security and dispute resolution, their implementation and the distribution of roles among (non-) state institutions largely determine the outcomes of reforms. This raises the question to what extent tenure reforms actually and effectively provide for the enhanced, coordinated and harmonised governance of land in the aftermath of the 2000 Arusha Peace Agreement in Burundi.

\section{Implementing land reforms, institutional proliferation and mixed outcomes: the case of Ngozi province}

The case of Ngozi province - the native region of the President Nkurunziza - profusely characterises the actual challenges and outcomes of the implementation of the land governance reforms grounded in the 2000 Arusha Peace Agreement (see Figure 1). Thirteen 


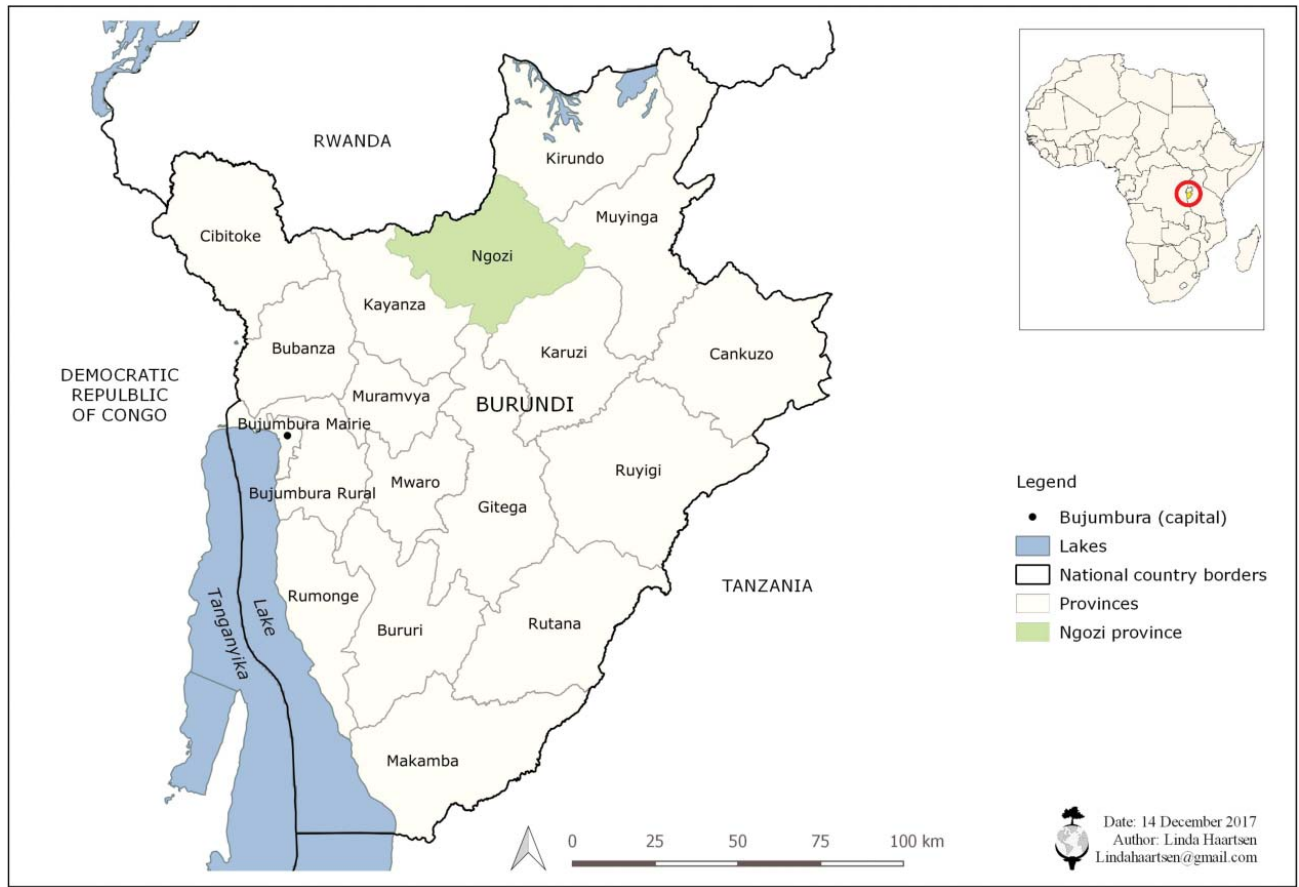

Figure 1. The 18 provinces of Burundi with Ngozi highlighted.

years ago, a high demographic pressure of about 445-800 inhabitants per $\mathrm{km}^{2}$, the long duration of internal displacement and the increasing land scarcity in Ngozi were already raising great concerns about the heightened competition for land and the relocation of former refugees and IDPs (APDH, CARE, and Global Rights 2004; International Crisis Group 2003). As in other conflict-affected regions of Burundi, the main sources of tenure insecurity in Ngozi have been the lack of official proof of land property rights and land disputes over land grabbing, irregularities in land sales, issues of women's land inheritance, contestations about the sharing of family land, competing claims for the restitution of pre-war land holdings, frequent contestations of past land arrangements, and disputes over the management and occupancy of agricultural marshland (APDH, CARE, and Global Rights 2004). These specific features have motivated the selection of this province as a pilot area for testing and implementing land governance reforms in the late $2000 \mathrm{~s}$.

Ngozi has been praised for being the first province in which all the nine communes run operational communal land registration offices and where the majority of land plots have been demarcated and recorded in the communal land registries. Three years before the adoption of the 2011 Revised Land Code, the Swiss Agency for Development and Cooperation (SDC) launched its decentralised land governance programme in two communes of Ngozi province: Ruhororo and Marangara (Bigirimana 2013b). By 2014, the SDC contributed to the creation of communal land registration offices in four other communes (Ngozi, Kiremba, Tangara and Nyamurenza), while the International Fund for Agricultural Development (IFAD) helped the remaining three communes (Gashikanwa, Busiga and Mwumba) in establishing their respective communal land registration offices (see Figure 2). By focusing on two key areas of land governance - the settlement of land 


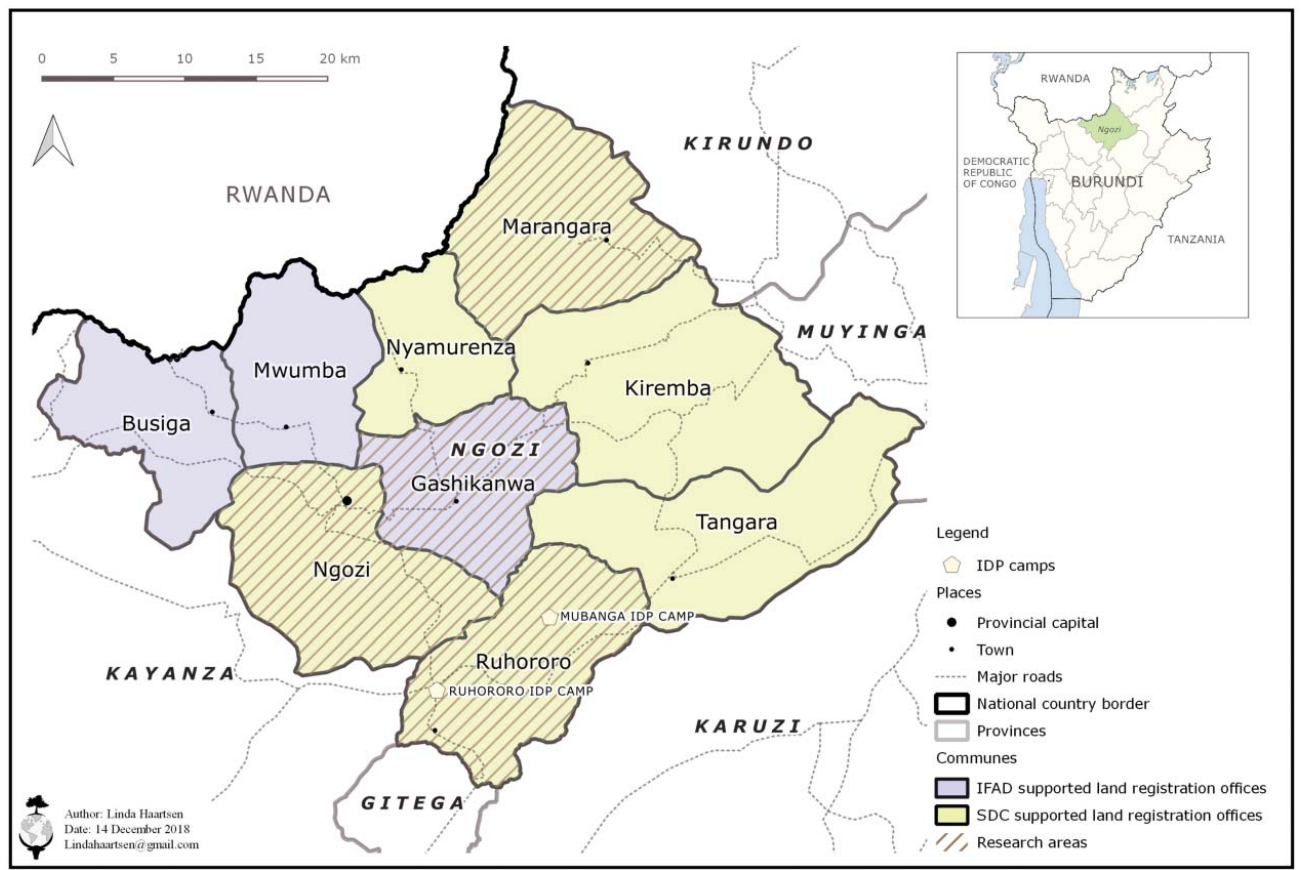

Figure 2. The communes of Ngozi province and the research areas mentioned in the case study.

disputes and the formalisation of property rights and administration of land - in the remainder of this section, I will examine how the changes in legislation and policies and the multiplication of regulations and institutions have impacted local security of tenure.

\section{The intricacies of land disputes resolution}

Of major concern in the official discourses and political debates since 2000 was the diversification and proliferation of land disputes, and thus the urgent need for empowering existing institutions and creating new institutions intervening in dispute resolution. During the fieldwork, all interviewees pointed out the differentiation between how displacement-related land disputes about the restitution of pre-conflict landholdings to refugees and from IDPs and how other general land disputes were approached by the state. More specifically, provincial authorities and NGOs agents involved in land certification projects emphasised the highly political sensitivity and imbroglio of displacement related land disputes in the IDP settlements in Ruhororo commune (see Figure 2).

\section{Dealing with general land disputes}

These land disputes included intra-family disputes about the division of family land, land boundaries encroachment, disputes on marshland, and contestations of past land sale agreements on family land by the younger generation. At the time of fieldwork, such disputes were mostly reported to and settled by customary leaders (family heads and traditional elders/bashingantahe) and local government authorities including ten-household heads, sub-hill chiefs, hill chiefs, area chiefs and/or the communal administration authorities. In the past, one hill chief was in charge of two or three hills, and the communal 
administrator was ruling without a communal council; the central government and the ruling party were appointing local government authorities. Nevertheless, since the signing of the 2000 Arusha Peace Agreement and the adoption of a multiparty and power-sharing model of government enshrined in the 2005 Constitution, there have been tremendous changes in the structure, the composition and sources of authority and legitimacy of local government authorities. Every commune is headed by a communal council and a communal administrator elected by and from local communities for five years on the basis of blotted lists of 30 (2005-2010) or 15 (since 2010) names of people affiliated to authorised political parties. At the hill level, rather than appointed individuals, there is a council of five hill chiefs playing the role of representatives of the communal administration; they are individually and politically elected by and from local communities for five years also, with the main hill chief being the person scoring the highest number of votes. The council of elected hill chiefs appoints sub-hill chiefs and ten-household heads after consulting with the communal administrator. Within a commune, hills are grouped in several areas, which are headed by area chiefs. For each area, the communal administrator appoints an area chief from the local communities and on the basis of its political affiliation. Local judges are appointed by the Minister of Justice for an undetermined period of time.

Regardless of the variability in the sources of authority and power, these institutional actors usually came from within the local communities and the province, and therefore shared a relatively good local knowledge and sense of "closeness" with one another and with local populations. For instance, despite the erosion of the legitimacy and authority of traditional elders (bashingantahe) (Kohlhagen 2010) and their exclusion from local governance by the central government in 2010 (Kohlhagen 2011b), they were still very much consulted in land disputes, and their ruling in intra-family land sharing and encroachment of land boundaries was well received in most communities. When one party involved in land disputes was not pleased with the solutions recommended by customary leaders and hill authorities, it was directed to the communal administration and the local court (tribunal de résidence). In case people wanted to appeal against a judgement rendered by the local court, the next judiciary representation was the High Court (tribunal de grande instance) in Ngozi town.

In general, most parties in land disputes would not bring their cases to the local courts due the financial constraints for covering judiciary fees and regular and multiple transactions and trips to the main city centres, the slowness of the judiciary process and increasing lack of confidence in the judiciary system (see Kohlhagen 2009). Sometimes, local judges would blindly apply the official legislation without proper verification of the authenticity of the testimonies and documents presented by the litigants. In other situations, such as cases about women's claims of exclusion in family land sharing, of eviction and dispossession by the family of late husbands, or even of domestic abuse and exclusion from accessing family land when their husbands take concubines, local judges, communal and hill chiefs invoked customary law, which marginalises vulnerable groups such as widows, daughters, unmarried women and unrecognised children in land affairs. Actually, even though the role of such authorities in dispute resolution is prescribed by the state legislation, it remains silent on the rules and procedures to apply for different land disputes in general, as well as on women's inheritance rights on land in particular. This legal gap allows communal and hill authorities to heavily rely on (personal interpretations of) customary norms and conventions, or enacting their own decisions, as they considered suitable. 
The specific case of disputes over marshland constitutes a remarkable setting of institutional multiplicity and ambiguity. As a matter of fact, the 2011 legislation recognises customary tenure over marshlands, but also that these are state-owned properties and therefore cannot be demarcated and registered by individuals and families ${ }^{12}$. Nevertheless, in localities with large areas of agricultural marshlands, their distribution and use are regulated by the decentralised government structures in charge of agriculture under the supervision of the governor of the province. In general, disputes about the types of crops to grow and agricultural techniques in use are marginal thanks to the intensive involvement of local representatives of the Ministry of Agriculture and the availability of agricultural inputs and technical support provided by several development aid programmes and projects such as PAIVA-B ${ }^{13}$ and PRODEFI ${ }^{14}$ from the International Fund for Agricultural Development. However, when disputes about the limits between adjacent plots and contested land transactions occurred, contestants preferred to refer to customary leaders who were very knowledgeable about customary tenure, land distribution among clans and lineages, and the evolution of the locations of the irrigating canals separating different family plots. Even local authorities at the hill level were much inclined to rely on the mediation and judgement of customary leaders when it concerned the marshlands. As the interviewees argued, most community members owning or using a piece of marshland were well aware they could not formally claim property rights over such land and therefore could not bring their disputes on marshland to government authorities out of fear of losing their access to those fertile land. Remarkably, they were feeling more secure on those land plots compared to hillside plots due to the resilience of informal and customary arrangements and the legitimacy of customary leaders in enforcing collectively binding norms in case of disputes.

Nonetheless, despite the diversity of local institutional authorities and the variability of their roles in dispute resolution, several interviewees from local communities considered that these authorities did not always fulfill the objectives of impartial arbitration/mediation and easily reachable dispute resolution. For instance, the traditional elders' practice of demanding for "local beer" either in cash or in kind before rendering their judgements was contested by community members organised in associations through the work of (inter) national NGOs. Moreover, given the extent of their responsibilities within local communities and that they received petty remuneration for their services on an irregular basis from the central government, hill chiefs ${ }^{15}$ and communal authorities requested (informal) "transportation" fees, and local judges set unofficial charges for their services. All these informal practices were detrimental to the protection of the interests and property rights of poorer parties in the disputes.

\section{Dealing with displacement-related land disputes}

Over its two years of operations, the CNRS did not contribute much to the resolution of displacement-related land disputes due to its centralised structure and limited funding (Bigirimana 2013a; Zeender and McCallin 2013). In contrast, the decentralisation of the $\mathrm{CNTB}$ at the provincial and communal levels was a prominent feature of its operations on the ground for reducing displacement-related land disputes. However, most government officials and representatives of civil society organisations and NGOs interviewed argued that the presence and impacts of this government structure were less visible in Ngozi province compared to the southern provinces of the country where the bulk of 
former refugees' claims to land were located $^{16}$ (Bigirimana 2013a; International Crisis Group 2003; OAG 2005; Sinarinzi and Nisabwe 1999).

Actually, the local populations of Ngozi were mainly internally displaced during the civil war; only a few proportion sought refuge outside the national borders. As argued by the CNTB officials, most returned refugees managed relatively well to retrieve their preconflict landholdings through the mediation of customary leaders, hill and communal authorities and the support received from the testimonies of their witnesses ${ }^{17}$. The achieved mutual arrangements for land restitution among the disputants were validated and formalised by the issuance of CNTB land certificates (CNTB 2012a, 2012b). In fact, the role of the central government in sensitising local communities about the repatriation operations and the need to give back part of or all the family land plots of returning refugees streamlined the implementation of the restitution process. In case the parties in land disputes failed to reach a consensus at the hill and communal levels, they were redirected to the CNTB provincial officials. After further investigation on the various claims and hearing of the witnesses, the CNTB provincial officials made a formal land sharing decision, mainly for the benefit of returnees. While the CNTB legal framework and policies have been revised in favour of full-land restitution instead of sharing arrangements through a presidential decree since 2011, many interviewees argued not being worried by the revised legislation because the majority of former refugees had recovered their landholdings before these reforms.

A well-known and noteworthy challenge faced by the CNTB and other local government authorities in Ngozi province was the aversion of the IDPs to leave the camps in which they have been resettled since the mid-1990s by the ruling authorities and with the help of international humanitarian organisations. Coupled to that were the contested claims of neighbouring communities for recovering their customary ownership rights on part of the land that was appropriated by former ruling authorities to accommodate IDPs $^{18}$ (APDH and Global Rights 2005). Even if the 2000 Arusha Peace Agreement strongly recommended the closure of IDPs camps ${ }^{19}$ and the return of IDPs to their prewar family landholdings, the majority of IDPs, however, withheld their land occupancy in the resettlement areas while simultaneously maintaining frequent access to and control over their family's land in nearby villages for farming. This situation fuelled violent contestations and clashes between IDPs and neighbouring communities on one side, and between IDPs and the local government authorities claiming that part of the contested land was state-owned land, and the CNTB provincial officials who issued an eviction notice against the IDPs on the other side ${ }^{20}$. The main justifications given by the IDPs interviewed about their reluctance and resistance to move out and to restitute the occupied land were grounded in feelings of insecurity and deep mistrust against the current political regime to protect their rights ${ }^{21}$. As one IDP in his late forties at the time of the fieldwork testified:

We (IDPs) want to remain here (IDP camp) because we do not feel safe in our hills of origin. What happened in 1993 might happen again; who knows? Even in 1993, we did not see the war coming; it struck us like that. We want to stay here, that's all! Our future is very uncertain... Educated people (government authorities and CNTB members) are the most dangerous. We lack confidence in our rulers. 
During the fieldwork, this complicated situation was described as a highly politically sensitive issue under the Nkurunziza regime, considering the social identity of the contestants in disputes, the CNTB and administrative provincial authorities, and the related politics. Actually, all remaining IDPs settlements included mono-ethnic populations Tutsis - who abandoned their family landholdings during the civil war and were relocated under the protection of the former Tutsi-led and militarised UPRONA regime (APDH and Global Rights 2005). In sharp contrast to the IDPs, the neighbouring communities claiming customary rights on IDPs settlements and government officials were identified as Hutus and/or pro-CNDD-FDD ${ }^{22}$ by IDPs. In this respect, some of these authorities were further accused of mobilising youth from within the current ruling party to infiltrate and attack IDP camps. As some key informants pointed out during informal conversations, despite the application of the policy of ethnic and political proportionality in the composition of government structures ${ }^{23}$, the majority of CNTB officials, the provincial governor and its counsellors, and the heads of provincial and communal police forces were mostly Hutus (and few Tutsis) appointed from within the ruling party (OAG 2013).

Whereas IDPs condemned the partiality of the government authorities and CNTB officials in supporting the claims and actions of neighbouring communities' members to evict them, most of these authorities denounced the rigidity of IDPs to positively respond to the public policy of land restitution and the state ruling. They vividly decried the alleged political allegiance of the IDPs for the party UPRONA, as well as the ambient ethno-political apathy and grievances grounded in historical power struggles and violence (see OAG 2013). Actually UPRONA leaders were harshly criticised for regularly touring IDPs settlements with political messages fuelling feelings of insecurity and presumptive life threats from the CNDD-FDD partisans, and therefore prompting IDPs to rebel against the government command to reintegrate their pre-war localities. In exchange of electoral votes, UPRONA leaders were also promising IDPs to permanently allocating them property rights and land titles on the disputed land and financing development projects in the camps $^{24}$ (see Chrétien 2002; Ndarishikanye 1999).

This imbroglio amplified the IDPs perception of the state as the enemy, and of the whole issue of compelling them to return to their pre-war localities as a strategy to silence them, considering that they would be scattered and more vulnerable against their former perpetrators $^{25}$. This led one representative from a civil society organisation to conclude that the current legislation has failed to solve the land problem on the Tutsi IDPs camps. Rather, this crucial land issue remains a political deadlock for central government authorities, which were unable to propose further solutions without exacerbating local tensions and creating far greater problems ${ }^{26}$. Confronted with such reality, IDPs strategically developed and reinforced a collective capacity to cope with their "hostile" environment through increasing exchanges of information, goods and services, and human resources and organising various social activities across different Tutsi IDPs settlements.

\section{The dualistic land registration and administration system}

By establishing localised land registration offices while preserving the existing land titling administration, the Burundian legislation has developed a dualistic land registration and administration system. The Land Titling and Cadastre offices, in collaboration with the decentralised structures of the MEEATU continued to respond to individual demands for 
demarcating and registering private property rights in Ngozi province. In parallel, these authorities were collaborating with the communal land registration offices for the identification, demarcation and production of land titles on state-owned land, prior to starting the registration of customary owned land.

The communal land registration office through the Commission de reconnaissance collinaire (hill surveying committee) was also responsible for assisting in the resolution of general land disputes. The composition of the hill surveying committee varied across different hills and communes. Theoretically, one representative of the communal administration and two nominated hill chiefs were de facto members of the hill surveying committee due to their formal administrative position and authority in local affairs. Hill chiefs had the duty to nominate one representative of the traditional elders at the hill level, based on his availability and local knowledge on customary land tenure. They also had to organise local elections for the selection of the remaining three members by and from local communities and local associations on the basis of their good reputation. However, in practice, several communal land agents and hill chiefs complained about the poor participation of communal representatives in regular land operations at the hill level due to their multiple and overlapping responsibilities at the communal level.

Considering that the legislation defines the role of the members of hill surveying committees as volunteering work, they were not regarded as paid workers either by the communal administration or by the supporting organisations coordinating the land certification projects. Subsequently, most hill surveying committee members were bitterly disappointed for not receiving a compensation in return for their full-time services in comparison to the communal land agents; for this reason, the rate of retraction from hill surveying committees was high in the first two to three weeks of activities. Therefore, in the land registration projects led by the SDC - focusing mainly on land demarcation and the production of certificates - various incentives in cash and in kind (school fees for children, small agricultural equipment, per diems, etc.) have been developed to increase the participation and commitment of the hill surveying committeemembers. However, the projects led by the IFAD, for which land certification was associated with agricultural development, failed to do the same because of financial restrictions. Besides, while the projects led by the SDC coupled individual and systematic land demarcation approaches ${ }^{27}$ in its areas of intervention in order to optimise its impacts on the ground, the projects led by the IFAD favoured the individual demarcation approach to align with the current legislation. These differences explained the gap observed between the communes supported by the SDC and IFAD in terms of the number of applications for land certificates, and the amount of land demarcated and registered.

In addition, the fees for acquiring a land certificate per land plot varied much across the communes, ranging from $3 \%$ to $10 \%$ of the purchased price for purchased land, or from $1500 \mathrm{BIF}$ to $30,000 \mathrm{BIF}$ (equivalent to USD 0.88 to USD 17.51 respectively) on other lands. Given that both the legislation on land and on the functioning of communes remained silent about the required fees to be applied for the deliverance of land certificates, each communal council had the autonomy to set its own range of land certificate fees. Such pricing was largely influenced by the amount of financial subsidy each commune received from external actors for the duration of projects, and the approach used for land demarcation. This locally based pricing practice was not seen to result in significant increase in the number of applications for land certificates. Communal land agents 
and representatives from the land certification projects interviewed imputed this to the poor living conditions of rural communities members and their reticence to apply for land certificates on customary and family held land. While most community members entrusted their customary leaders to maintain their authority on customary land tenure, others were not ready to proceed to the division of family land among the family members yet. In fact the continuous division of family land over generations had resulted in a critical decrease of plot surfaces and increasing competition among close relatives. Since the introduction of land certification, such land disputes were occurring not only within the same generation after the death of the family head, but also between parents and their male descents claiming their portion of customary land inheritance.

Most interviewees pointed out that the majority of community members paying their land certificates fees were owners of purchased land and middle-class people. A significant proportion of registered purchased land plots were located in urban neighbourhoods such as Ngozi city. Considering the high costs related to cadastral and land titling processes for the average citizen, the 2011 legislation provided for the possibility to transform land certificates into land titles ${ }^{28}$; therefore, urban landowners in Ngozi city for instance were more inclined to register their property rights with the communal land registration offices. Consequently, officials from the provincial cadastre and land titling structures perceived this practice as encroaching upon their jurisdiction and authority in formalising property rights in urban areas, which emerged into tensions between the parallel land registration administrations on the ground. The great amount of subsidies and technical support allocated to the staff of the communal land registration offices were also a considerable cause of discontent for the cadastral and land titling officials.

The establishment of a localised land registration and administration was much instrumental in improving the security of tenure on state-owned land and the authority of decentralised government officials. Thanks to foreign aid, the implementation of the reforms contributed to the retrieval of property rights on irregularly appropriated state land during the periods of violent conflicts, and reinforcing the role of cadastre and land titling authorities in this. Besides, entrenching the local demarcation and registration of land in the communal administration was effective in boosting the authority and legitimacy of the communal council and administration on the rural populations and within the government system. However, the coexistence of a dual land registration and administration had substantial impacts for the notions of securing land tenure and the role of the central government at the local level.

Actually, the promotion of land certification minimised the need for land titles and, in this, the role of the related local government structures. Even though many interviewees were not sure about the legal differentiation between land titles and land certificates, they believed that land certificates were offering the same benefits as land titles in terms of formal securing of tenure, prevention of land disputes, and access to financial credit. While there was hardly any evidence of a direct effect between holding a land certificate and being granted credits by local financial institutions, land certificate holders were much convinced about the protection of their property rights against further competing claims from within local communities. This strong feeling of security of tenure emerged from the public land demarcating operations under the supervision of communal land agents, and in the presence of the representatives of customary leaders, communal and hill authorities, and from the consensual arrangements on land boundaries. Hence, in case of 
further forced displacement, local land users strongly believed that the communal land certificates registries would support their land claims and speed up land dispute resolution. At the same time, they expected that recording local land boundaries and property rights, and keeping communal land certificates registries might enhance the rule of law in the future, even in case of political upheaval.

The composition and the voluntary compliance of hill surveying committees provided through the current legislation considerably increased the relative importance of existing traditional elders as custodians of customary land tenure and of hill authorities for assessing local claims of land ownership. The participation of representatives of traditional elders in the hill surveying operations provided community members with a sense of security based on the historical role of these authorities as the custodians of local landownership. Yet, traditional elders were not allowed by their peers to make decisions on land disputes outside the council of traditional elders. Subsequently, when communal land agents and the local government authorities supervising the surveying of the land failed to reach arrangements on land boundaries and competing claims of landownership, they were not recording the cadastral information on the contested land; instead, they were redirecting the contestants toward their family councils, the council of traditional elders, the council of hill chiefs or the local court of justice.

In parallel, at the time of fieldwork, on-going debate persisted to what extent the new land registration and administration contributed to securing land tenure. Strikingly, the endorsement of the land certification procedure by the central government also induced perceptions of insecure land tenure, by largely spreading the information that not allowing for the demarcation of one's owned land during the systematic hill surveying operations was considered a serious offence against the central government. This led some community members consider that the expansion of land demarcation aimed at assessing citizens' land properties for the future design and implementation of a major taxation system. Other community members exploiting marshlands also imagined that local land surveying helped the state to locate and register such land by the cadastre and land titling authorities for further expropriation.

Such mixed feelings of tenure insecurity against the state were also shared about the communal administration. At the time of fieldwork, most communal land registration offices were still benefiting from the financial and technical support through the land certification projects, and therefore from a relatively good stability of the hired personnel and the regularity of the members of hill surveying committees thanks to a significant bonus system. However, based on observations from other communal land registration offices in other provinces that had run out of external subsidies, some interviewees expected that, at the end of the largely funded projects, the communal administration and communal land agents might raise the land certificate fees in order to cover the costs involved in the land certification process and in the functioning of the communal land registration offices. In this respect, rent-seeking practices might emerge and therefore threaten the credibility of communal authorities and members of hill surveying committees for protecting the property rights and claims of poor people, as well as the sustainability of the land certification process ${ }^{29}$. 


\section{Challenging dynamics in local land governance}

In the aftermath of the 2000 Arusha Peace Agreement, land governance reforms were envisaged reorganising and assisting land-governing institutions in enhancing tenure security through reducing land disputes, expanding the formalisation of property rights with the aim of fostering peace-building at the local level. Nevertheless, as demonstrated through the case study of Ngozi province, such reforms actually contribute to the proliferation of institutions, trigger the exclusion of particular institutions and increase confusion about the roles played by different institutions through multiplying the rules, norms and conventions to apply and providing various institutions with overlapping or limited authority and legitimacy on land.

Thereby, those reforms have induced ambiguous impacts on the institutional setting for land services provision and on the legitimacy of land-governing practices on the ground. In Ngozi province, reforms in land governance have produced a patchy institutional set-up in which customary land tenure and institutions are progressively being absorbed within the statutory system, which threatens the resilience of customary land arrangements and practices. Throughout past decades of violence and political turmoil, the repeated efforts of the successive governments to reform the legal and institutional frameworks in land governance, and to promote the individualisation and formalisation of property rights have restricted the power and role of customary institutions as guardians of local land tenure and mediators in dispute resolution. Yet, despite the limited legitimacy they receive through the state, the authority of customary institutions continues to be recognised by local people. Consequently, in a situation where customary tenure guarantees a relatively good level of security on property ownership, designing and implementing new policy of registering land rights may not increase it (APDH and Global Rights 2005).

As the case of Ngozi province also shows, the implementation of the new legislation on land registration adds to institutional multiplicity and complexity by creating a parallel land administration, increasing the responsibilities and tasks of existing communal and hill authorities, and traditional elders in the mediation of local land disputes and the surveying of land, and reshuffling the roles and power of different government authorities. In this, the reforms also stimulate conflicting relations of authority and legitimacy between different government structures. Despite the interferences they create and fuel in decision-making and land governing practices, they certainly contribute also to establish, maintain and reinforce the local presence, authority and control of the Nkurunziza government over land. Nevertheless, the reforms paradoxically contribute to developing scepticism and indeterminacy against the state. The government continues to be perceived as not reliable by a portion of the local populations. Actually, some local people believe that most reforms are intended to limit their access to and benefits from land.

Moreover, the persistent disputes related to the land occupied by the IDPs settlements over the past decades underscore how past violence and forced displacement can result in protracted contestations about land and mingle with ethno-political antagonism and manipulation. It is therefore not surprising that while new policies, legislation, institutions and governing practices have contributed to mitigating many land disputes and to legitimise property ownership in many communities, they have remained unsuccessful in 
conciliating diverging claims and pacifying tenure relations over the land occupied by Tutsi IDPs. This institutional impasse has caused local people to limit confidence in the capacity of the current government to question effectively the validity of competing claims on land and to take responsibility for decisions and practices of former governments. As a matter of fact, when certain disputes over land rights find their roots in past civil violence and unclear and contested tenure arrangements, governance reforms alone may not be sufficient to reorganise local tenure relations and to improve secure land tenure. The case of Burundi provides critical insights on the need for greater sensitivity to the impacts of a long history of governance reforms in changing and ethno-politically volatile settings on land tenure relations and power dynamics at the local level. This aligns with previous analyses of land reforms and land disputes in Burundi (see International Crisis Group 2014a; International Crisis Group 2014b; Kohlhagen 2011a) which highlight the importance for Burundian policy makers and development aid agencies to move beyond simplistic and broader understanding of and approaches to complex land disputes and tenure insecurity in the aftermath of the 2000 Arusha Peace Agreement in favour of a more inclusive and socially sensitive agrarian and land reform that reconciles statutory and customary institutions and processes in land service provision and dispute resolution. Likewise, the way in which land-related local conflicts are interpreted and the extent to which local conflicts resolving institutions and arrangements are considered will have implications for legitimising the authority of government institutions and the state in local land governance.

\section{Notes}

1. Burundi is a densely populated country, with a size of $27,836 \mathrm{~km}^{2}$ and an estimated population of nearly $11,900,000$ inhabitants, of whom more than $90 \%$ are still depending on subsistence agriculture. The combination of these factors with land scarcity and poverty put the majority of its population at risk of food insecurity.

2. The hill or colline is the most basic administrative unit in Burundi.

3. Edict of the Mwami no. 5 of 10/08/1961.

4. See Durand-Lasserve (2006), Lemarchand (1996), Wittig (2016) and van Acker (2016).

5. For example: Land allocation decisions issued by the communal administrator of Rumonge following the letter of the Governor of Bururi on 18/08/1972 instructing for the distribution of land properties of the exiled Hutu 'rebels'.

6. Decree-Law no. 1/191 of 30 December 1976.

7. Decree-Law no. $1 / 19$ of 30 June 1977 stating the abrogation of the institution Ubugererwa.

8. Decree-Law no. $1 / 20$ of 30 June 1977. Before this decree, the prescription rule was only applicable on registered land.

9. See the 2000 Arusha Peace Agreement, Protocol IV, Chapter 1, Article 8.i, p.89.

10. Pierre Nkurunziza is the former leader of the Hutu rebel group called the Conseil National pour la Défense de la Démocratie et Forces de Défense de la Démocratie (CNDD-FDD), which became the dominant political party since 2005.

11. See Article 263 of the Burundian Constitution of 18 March 2005; and Law no. 1/02 of 25 January 2010 revising the Law no. 1/16 of 20 April 2005 on the organisation of the communal administration.

12. 2011 Land Code, Art. 438 to 451.

13. Programme d'appui à l'intensification et à la valorisation de l'agriculture au Burundi.

14. Programme de développement des filieres. 
15. In fact, only the first hill chief receives a petty and variable remuneration depending on the financial capacity of the communal administration. Because the other four hill chiefs, area chiefs, sub-hill chiefs and heads of ten households were unpaid, most of the time they were not much involved in local dispute resolution; otherwise, they were asking contestants in land disputes for informal compensation for their services.

16. Interviews, communal administrators Ruhororo, Marangara, Ngozi (9 and 12 May 2014). A detailed analysis of the role of the CNTB in the resolution of land disputes involving former refugees is presented in a separate article by the author in collaboration with Han van Dijk.

17. In the absence of official proof of property rights on customary land, customary leaders and government officials were considerably relying on oral accounts provided by two or three witnesses selected by each party in the dispute. The great challenge was the assessment of the accuracy of the oral statements, especially because most elderly people with reliable local knowledge on customary land tenure before the protracted conflicts have died.

18. Iwacu, 'Site Ruhororo: bras de fer engagé entre la CNTB et les déplacés', 04 May 2012, http://www.iwacu-burundi.org/site-ruhororo-bras-de-fer-engag-entre-la-cntb-et-les-dplacs-2/ (8 August 2016).

19. For more details on the internal displacement in Burundi, see International Crisis Group $(2015,2016)$.

20. Interviews, communal administration Ruhororo (9 May 2014); representative of a civil society organisation Ngozi (14 May 2014); IDPs (8 July 2014). Armel-Gilbert Bukeyeneza (Iwacu), 'Affrontements entre jeunes du sites des déplacés de Ruhororo et la police.' Iwacu, 27 November 2013, http://www.iwacu-burundi.org/site-des-deplaces-de-ruhororo-un-baril-a-poudre/ (8 August 2016).

21. Interviews, Ruhororo camp (25 June, 8 July 2014); Mubanga camp (8 July 2014).

22. Interviews, IDPs (8 July 2014).

23. The 18 March 2005 Constitution, Art. 129, 143, 164 and 168. The handbook of administrative and financial procedures of communes, section II.1.1.

24. Interviews, representative of a civil society organisation (14 May, 3 September 2014).

25. Interviews, IDPs (8 July 2014).

26. Interview, Ngozi (3 September 2014).

27. The 2011 Land Code does not specify the approaches for land demarcation in the certification/ registration process.

28. 2011 Land Code, Art. 410.

29. Seminar gathering communal council members, communal administrators and communal land agents to discuss the challenges land certification in Burundi, 16-17 October 2014.

\section{Acknowledgement}

The author is very grateful to Han van Dijk, Gemma van der Haar and Mathijs van Leeuwen and anonymous reviewers for their critical insights and comments on preliminary versions of this paper, to Pamela, Esperance and Steve for their tremendous and invaluable support during and after fieldwork, and to the numerous interviewees that were willing to share their stories and perspectives with the researcher. Any mistakes and misinterpretations are entirely my own.

\section{Disclosure statement}

No potential conflict of interest was reported by the author.

\section{Funding}

This work is supported by NWO-WOTRO Science for Global Development, The Netherlands [grant number W01.65.332.00]. 


\section{ORCID}

Rosine Tchatchoua-Djomo (iD) http://orcid.org/0000-0002-0394-5291

\section{References}

APDH,CARE, and Global Rights. 2004. Enquête qualitative sur la situation des conflits fonciers dans la province de Ngozi. Bujumbura: APDH, CARE \& Global Rights.

APDH, and Global Rights. 2005. Document de plaidoyer sur la problématique foncière dans la province de Ngozi: Cas des sites de Mubanga, Kibezi, Tangara, Vyerwa, Ruhororo, Mubuga et Rukeco. Bujumbura: Association pour la Paix et les Droits de l'Homme (APDH) \& Global Rights.

Berry, Sara. 2009. "Property, Authority and Citizenship: Land Claims, Politics and the Dynamics of Social Division in West Africa." Development and Change 40(1): 23-45.

Betge, David, Jean Pierre Irutingabo, and Hendrik Westerbeek. 2017. "The Missing Link: Successes and Lessons Learned from an Integrated Approach to Land Tenure Registration in Burundi", paper presented at the Annual World Bank Conference on Land and Poverty, 20-24 March, WashingtonDC: World Bank.

Bigirimana, Gilbert. 2013a. Analyse juridique de la problématique du contentieux foncier impliquant les sinistrés: oeuvre des commissions et des juridictions. Bujumbura: Commission Episcopale Justice et Paix (CEJP).

Bigirimana, Gilbert. 2013b. Mémento du Droit Foncier Burundais. Bujumbura: Direction du Développement et de la Coopération Suisse (DDC) and Global Rights.

Boone, Catherine. 2013. "Land Regimes and the Structure of Politics: Patterns of Land-Related Conflict." Africa 83(1): 188-203. doi:10.1353/afr.2013.0005.

Bukera, Joseph. 1970a. "L'immatriculation des terres au Burundi." Revue Juridique et Politique: Indépendance et Coopération 24(4): 745-746.

Bukera, Joseph. 1970b. "Les droits fonciers coutumiers au Burundi." Revue Juridique et Politique: Indépendance et Coopération 24(4): 1207-1214.

CNTB. 2012a. Journées d'information sur les activités de la CNTB. Bujumbura: Commission Nationale des Terres et autres Biens (CNTB).

CNTB. 2012b. Mémorandum sur les réalités de la CNTB: Contexte historique et juridique, fonctionnement et réalisations, grands défis et propositions de solutions. Bujumbura: Commission Nationale des Terres et autres Biens (CNTB).

Chrétien, Jean-Pierre. 2002. Burundi, la fracture identitaire: logiques de violence et certitudes ethniques, 1993-1996. Paris: Karthala.

Crisp, Jeff. 2010. "Forced Displacement in Africa: Dimensions, Difficulties, and Policy Directions." Refugee Survey Quarterly 29(3): 1-27. doi:10.1093/rsq/hdq031.

Durand-Lasserve, Alain. 2006. "Informal Settlements and the Millennium Development Goals: Global Policy Debates on Property Ownership and Security of Tenure." Global Urban Development 2(1): 1-15.

Fischer Clara, and Ruth Vollmer (eds). 2009. Migration and Displacement in Sub-Saharan Africa: The Security-Migration Nexus II. Bonn: Bonn International Center for Conversion (BICC).

Green, Arthur. 2013. "Title Wave: Land Tenure and Peacebuilding in Aceh." In Land and Post-Conflict Peacebuilding, edited by Jon Darrel Unruh and Rhodri Caitlin Williams, 293-319. London: Earthscan.

Griffiths, John. 1986. "What is Legal Pluralism?" The Journal of Legal Pluralism and Unofficial Law 18(24): 1-55.

Hirblinger, Andreas T. 2015. "Land, Political Subjectivity and Conflict in Post-CPA Southern Sudan." Journal of Eastern African Studies 9(4): 704-722. doi:10.1080/17531055.2015.1105443.

International Crisis Group. 2003. Refugees and Displaced in Burundi: Defusing the Land TimeBomb, Africa Report No. 70. Nairobi: International Crisis Group (ICG).

International Crisis Group. 2014a. Fields of Bitterness (I): Land Reform in Burundi, Africa Report No. 213. Nairobi: International Crisis Group (ICG). 
International Crisis Group. 2014b. Fields of Bitterness (II): Restitution and Reconciliation in Burundi, Africa Report No. 214. Nairobi: International Crisis Group (ICG).

International Crisis Group. 2015. Burundi: Sacrified Peace?, Africa Briefing No. 111. Nairobi: International Crisis Group (ICG).

International Crisis Group. 2016. Burundi: A Dangerous Third Term, Africa Report No. 235. Nairobi: International Crisis Group (ICG).

Joireman, Sandra Fullerton, and Laura S. Meitzner Yoder. 2016. “A Long Time Gone: Post-Conflict Rural Property Restitution Under Customary Law.” Development and Change 47(3): 563-585. doi:10.1111/dech.12236.

Justin, Peter Hakim, and Mathijs van Leeuwen. 2016. "The Politics of Displacement-Related Land Conflict in Yei River County, South Sudan.” The Journal of Modern African Studies 54(3): 419-442. doi:10.1017/S0022278X16000239.

Kamungi, Prisca Mbura, Johnstone Summit Oketch, and Chris Huggins. 2005. "Land Access and the Return and Resettlement of IDPs and Refugees in Burundi." In From the Ground Up: Land Rights, Conflict and Peace in Sub-Sahara Africa, edited by Chris Huggins and Jenny Clover, 195-267. Pretoria: Institute for Security Studies.

Kobusingye, Doreen Nancy, Mathijs van Leeuwen, and Han van Dijk. 2016. "Where Do I Report My Land Dispute? The Impact of Institutional Proliferation on Land Governance in Post-Conflict Northern Uganda." The Journal of Legal Pluralism and Unofficial Law 48(2): 238-255. doi:10.1080/07329113.2016.1195673.

Kohlhagen, Dominik. 2009. Burundi: La justice en milieu rural. Brussels: RCN Justice \& Démocratie.

Kohlhagen, Dominik. 2010. "Le bushingantahe au Burundi: Transformations et réminiscences d'un concept judiciaire ancien." In Cahiers d'Anthropologie du Droit 2009. Dire le droit, rendre la justice, edited by Laboratoire d'Anthropologie Juridique de Paris, 113-128. Paris: Karthala.

Kohlhagen, Dominik. 2011a. "In Quest of Legitimacy: Changes in Land Law and Legal Reform in Burundi." In Natural Resources and Local Livelihoods in the Great Lakes Region of Africa. A Political Economy Perspective, edited by A. N. Ansoms and S. Marysse, 83-103. Basingstoke: Palgrave Macmillan.

Kohlhagen, Dominik. 2011b. "Les Bashingantahe écartés de la loi: la place de la justice traditionnelle burundaise après la loi communale de 2010.” In L'Afrique des Grands Lacs, Annuaire 2009-2010, edited by Filip Reyntjens, S. Marysse, and Stef Vandeginste, 19-32. Paris: L'Harmattan.

Lavigne Delville, Philippe. 1999. Harmonising Formal Law and Customary Land Rights in FrenchSpeaking West Africa. London: International Institute for Environment and Development (IIED).

Lemarchand, René. 1996. Burundi: Ethnic Conflict and Genocide. WashingtonDC: Woodrow Wilson Center Press.

Lund, Christian, and Catherine Boone. 2013. "Introduction: Land Politics in Africa - Constituting Authority Over Territory, Property and Persons." Africa 83(1): 1-13. doi:10.1017/ S000197201200068X.

Lund, Christian. 2011. "Property and Citizenship: Conceptually Connecting Land Rights and Belonging in Africa." Africa Spectrum 46(3): 71-75.

McCallin, Barbara. 2012. Restitution and Legal Pluralism in Contexts of Displacement, Case Studies on Transitional Justice and Displacement. New York: International Center for Transitional Justice (ICTJ).

McCallin, Barbara. 2013. "The Role of Restitution in Post-Conflict Situations." In Land and Post-Conflict Peacebuilding, edited by Jon Darrel Unruh and Rhodri Caitlin Williams, 99-114. London: Earthscan.

Meinzen-Dick, Ruth, and Rajendra Pradhan. 2002. "Legal Pluralism and Dynamic Property Rights." CAPRi Working Paper 22, 1-41.

Munezero, Camille, and Réné Claude Niyonkuru. 2016. "The Veiled Side of Land Certification at the Communal Level in Burundi: A New Regard at Women's Land Rights”, paper presented at the Annual World Bank Conference on Land and Poverty, 14-18 March, Washington DC: World Bank. 
Ndarishikanye, Barnabé. 1999. "Burundi: des identités ethnico-politiques forgées dans la violence." Canadian Journal of African Studies/Revue canadienne des études africaines 33(2-3): 231-291. doi:10.1080/00083968.1999.10751163.

Ndayirukiye, Sylvestre, and Shinichi Takeuchi. 2014. "Dealing with Land Problems in Post-Conflict Burundi." In Confronting Land and Property Problems for Peace, edited by Shinichi Takeuchi, 109-129. London and New York: Routledge.

Nyenyezi Bisoka, Aymar, and An Ansoms. 2012. "Arène foncière au Burundi: Mieux comprendre les rapports de force.” In L'Afrique des Grands Lacs: Annuaire 2011-2012, edited by Filip Reyntjens, S. Marysse, and Stef Vandeginste, 37-58. Paris: L'Harmattan.

OAG. 2005. Evaluation de la politique sectorielle de rapatriement, de réinsertion et de réhabilitation des sinistrés au Burundi. Bujumbura: Observatoire de l'Action Gouvernementale (OAG).

OAG. 2013. Analyse de l'organisation et du fonctionnement de la Commission Nationale des Terres et Autres Biens: Une épine dans le processus de consolidation de la paix et de la réconciliation nationale. Bujumbura: Observatoire de l'Action Gouvernementale (OAG).

Peluso, Nancy Lee, and Christian Lund. 2011. "New Frontiers of Land Control: Introduction." Journal of Peasant Studies 38(4): 667-681. doi:10.1080/03066150.2011.607692.

Sikor, Thomas, and Christian Lund. 2009. "Access and Property: A Question of Power and Authority.” Development and Change 40(1): 1-22. doi:10.1111/j.1467-7660.2009.01503.x.

Sinarinzi, Félicien, and Théodora Nisabwe. 1999. Etude sur la problématique des terres laissées par les réfugiés de 1972 dans les communes Rumonge et Nyanza-Lac. Bujumbura: Présidence de la quatrième commission des négociations interburundaises d'Arusha, chargée du développement et de la reconstruction.

Tegnan, Hilaire. 2015. "Legal Pluralism and Land Administration in West Sumatra: The Implementation of the Regulations of Both Local and Nagari Governments on Communal Land Tenure." The Journal of Legal Pluralism and Unofficial Law 47(2): 312-323. doi:10.1080/ 07329113.2015.1072386.

Todorovski, Dimo. 2016. "Facilitating State-Building - Post-Conflict Land Administration." GIM International, 26-27.

Unruh, Jon Darrel, and Rhodri Caitlin Williams. 2013. “Land: A Foundation for Peacebuilding.” In Land and Post-Conflict Peacebuilding, edited by Jon Darrel Unruh and Rhodri Caitlin Williams. London: Earthscan.

Unruh, Jon Darrel. 2003. "Land Tenure and Legal Pluralism in the Peace Process." Peace and Change 28(3): 352-377.

Unruh, Jon Darrel. 2005. "Property Restitution Laws in a Post-War Context: The Case of Mozambique.” African Journal of Legal Studies 1(3): 147-165. doi:10.1163/221097312x13397499736183.

Wittig, Katrin. 2016. "Politics in the Shadow of the Gun: Revisiting the Literature on 'Rebel-toParty Transformations' Through the Case of Burundi." Civil Wars 18(2): 137-159. doi:10.1080/ 13698249.2016.1205561.

Zeender, G., and B. McCallin. 2013. "Durable Solutions for Internally Displaced Persons in Burundi Within Reach.” Refugee Survey Quarterly 32(1): 74-100. doi:10.1093/rsq/hds024.

de Clerck, Louis. 1970. "Le domaine des collectivités publiques au Burundi." Revue Juridique et Politique: Indépendance et Coopération 24(4): 801-814.

de Clerck, Louis. 1971. "Le régime foncier du Burundi." Revue Administrative et Juridique du Burundi 1: 1-16.

van Acker, Tomas. 2016. "Exploring the Legacies of Armed Rebellion in Burundi's Maquis Par Excellence.” Africa Spectrum 51(2): 15-37.

van Leeuwen, Mathijs. 2010. "Crisis or Continuity? Framing Land Disputes and Local Conflict Resolution in Burundi.” Land Use Policy 27(3): 753-762. doi:10.1016/j.landusepol.2009.10.006.

van Leeuwen, Mathijs. 2017. "Localizing Land Governance, Strengthening the State: Decentralization and Land Tenure Security in Uganda." Journal of Agrarian Change 17(1): 208-227. doi:10.1111/joac.12143.

von Benda-Beckmann, Keebet. 1981. "Forum Shopping and Shopping Forums: Dispute Processing in a Minangkabau Village in West Sumatra." Journal of Legal Pluralism 19: 117-158. 